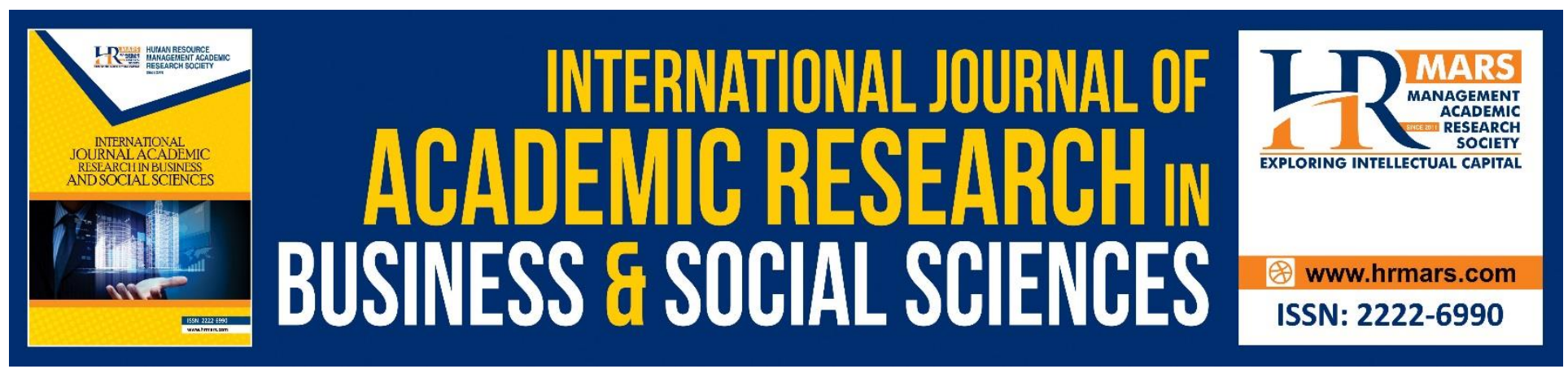

\title{
How Cohesive are You in Virtual Communities?
}

\section{Hamizah Sahharon, Jusang Bolong, Siti Zobidah Omar, Khairuddin Idris}

To Link this Article: http://dx.doi.org/10.6007/IJARBSS/v10-i15/8246

DOI:10.6007/IJARBSS/v10-i15/8246

Received: 27 September 2020, Revised: 18 October 2020, Accepted: 11 November 2020

Published Online: 27 November 2020

In-Text Citation: (Sahharon et al., 2020)

To Cite this Article: Sahharon, H., Bolong, J., Omar, S. Z., \& Idris, K. (2020). How Cohesive are You in Virtual Communities? International Journal of Academic Research in Business and Social Sciences, 10(15), $233-252$.

Copyright: () 2020 The Author(s)

Published by Human Resource Management Academic Research Society (www.hrmars.com)

This article is published under the Creative Commons Attribution (CC BY 4.0) license. Anyone may reproduce, distribute, translate and create derivative works of this article (for both commercial and non-commercial purposes), subject to full attribution to the original publication and authors. The full terms of this license may be seen

at: $\underline{\text { http://creativecommons.org/licences/by/4.0/legalcode }}$

Special Issue: Youth and Community Wellbeing: Issues, Challenges and Opportunities for Empowerment V1, 2020, Pg. 233 -252 http://hrmars.com/index.php/pages/detail/IJARBSS

Full Terms \& Conditions of access and use can be found at http://hrmars.com/index.php/pages/detail/publication-ethics 


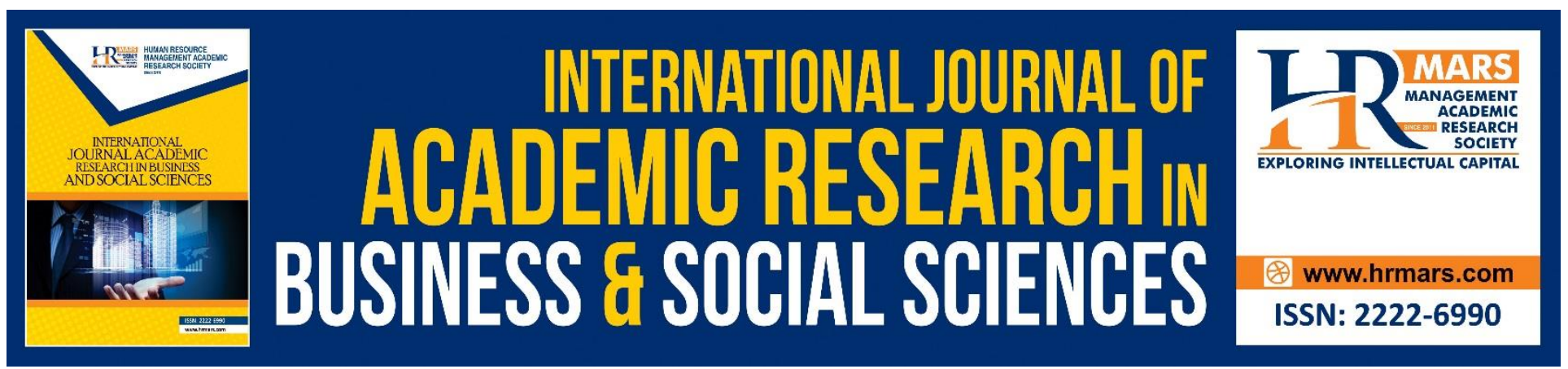

\title{
How Cohesive are You in Virtual Communities?
}

\author{
Hamizah Sahharon ${ }^{1}$, Jusang Bolong ${ }^{2,1}$, Siti Zobidah Omar²,1, \\ Khairuddin Idris ${ }^{1}$ \\ ${ }^{1}$ Institute for Social Science Studies, Universiti Putra Malaysia (UPM), Putra Infoport \\ 43400 Serdang, Selangor, Malaysia, ${ }^{2}$ Faculty of Modern Language and Communication, Universiti \\ Putra Malaysia (UPM), 43400 Serdang, Selangor, Malaysia \\ Email: jusang@upm.edu.my (JB)
}

\begin{abstract}
Although a cohesive society is difficult to maintain, social cohesion is seen as ideal to unite a heterogeneous community. Studies in the past have focused on social cohesion within real life context involving face-to-face encounters, nowadays it was noted that social networking sites (SNS) have a role in determining the level of social cohesion. This study aims to examine the role of SNS in determining the level of social cohesiveness among its virtual youth communities' members. A total of 600 multiethnic youths in urban and rural areas in Malaysia were selected based on a multi-stage cluster sampling technique. The respondents were asked to state their level of agreement on sense of togetherness, sense of belonging, social trust, and social interaction through a distributed selfadministered questionnaire. The results showed that the overall level of social cohesion among virtual youth communities was only moderate and the dimension sense of belonging yielded the highest score. This study implied that SNS are capable of enhancing the level of social cohesion among youths in Malaysia.
\end{abstract}

Keywords: Virtual Community, Social Cohesion, Cohesiveness, Communication, Youth

\section{Introduction}

Social cohesion is defined as the sum of the positive forces that works towards the well-being of all members, fights racial exclusion and marginalization, creates a sense of belonging, promotes trust, and offers its members the opportunity of upward mobility (Hogg, 1992). The term social cohesion is defined through the simple cluster of socially 'desirable' individual traits within groups and communities such as trust, tolerance, and active membership. It was in 1897 that a French sociologist, Emile Durkheim conceptualizes social cohesion as a norm and values of a collective social behavior. He studied the social phenomena from the perspective of social integration, religion and suicide and how individuals act to feel connected to a collective society (Pahl, 1991). 
INTERNATIONAL JOURNAL OF ACADEMIC RESEARCH IN BUSINESS AND SOCIAL SCIENCES

Vol. 10, No. 15, Youth and Community Wellbeing: Issues, Challenges and Opportunities for Empowerment V1. 2020, E-ISSN: 2222-6990 @ 2020 HRMARS

In Asia, Khan (2001) and DeVito (2009) claimed that Asian values are family-oriented and privileged society over individualism. The welfare of the whole society is put above the individuals, which is why social cohesion plays an important role in building interdependent relationships. The concept of social cohesion does not incite individuals to share the same opinion, but more to do with the mutual attraction between members from different background; it is a measure of interdependence and the extent to which individuals work together as one (Thibaut \& Kelley, 1959). Cartwright (1968) then stated in his theory that social cohesion is different as it is the sum of the positive forces of different individuals have in each member's life-space and this phenomenon is the consequence of different forces acting on all the members to remain within the group.

Rising income inequality (Wilkinson \& Pickett, 2009; Burhan, Sidek, Kurniawan, and Mohamad, 2015; Mohamad, Jusoh, \& Kassim, 2019), unemployment and crime (Jenson, 1998; Shawkat, 2010; Smith, 2010), and a rise of a more individualized generation have been the cause of the decline in social cohesion (Putnam, 2000). According to Oliveri (2005), to tackle the causes of social insecurity is through enhancing the sense of social cohesion in our society as it provides a sense of security and social inclusion to the people who are fearful, and the feared. A tool that can enhance the sense of social cohesion is through SNS; it can be more than a medium for communication. Interaction via SNS epitomizes a widespread process of interaction with cognition (Fischer \& Reuber, 2011).

In two studies on Twitter (Fischer \& Reuber, 2011; Purohit, Ruan, Fuhry, Parthasarathy \& Sheth, 2014), they found that online users recognized how Twitter has a community dynamic that helped disseminate information that people might not generally share, which resulted in a greater sense of trust and social identity among their customers. However, the number of research studies that examined social cohesion within virtual communities was minimal. There is little specific research conducted into the types of interactions within virtual communities that may be used to provide such emotional support and enhance the member's sense of belonging or community.

Computer-mediated communication is seamless with interpersonal communication and becomes more apparent with the era of modernization. The emerging SNS such as Facebook, Twitter, and Instagram for example, has induced youths to become more accustomed to using the internet as a medium for conveying messages. Thus, leading us to question; what is the level of social cohesion among virtual community members? Hence, this paper aims to examine the role of SNS in determining the level of social cohesiveness among Malaysian virtual youth communities.

\section{Interrelated Theories of Social Cohesion}

Social cohesion is conceptualized based on the interrelated theoretical assumptions made by different academic fields with respect to one another being an antecedent, intervening or outcome variables (Friedkin, 2004; Bruhn, 2009; Mansor, 2014; Saripudin \& Komalasari, 2015). Theorists from the sociological, psychological and communication fields believe that social cohesion results from an innate sense of togetherness or belonging to the society as a whole. Since year 1377 to 1993 , different philosophical fields have influenced the understanding on the concept of social cohesion. The concept started from the sociological field, which then extends its concept to the communication and social psychological field. Each theory predicts the nature of human society and explains the communicative processes or exchange between individuals in a group or community in general to develop the sense of social cohesion. 
INTERNATIONAL JOURNAL OF ACADEMIC RESEARCH IN BUSINESS AND SOCIAL SCIENCES

Vol. 10, No. 15, Youth and Community Wellbeing: Issues, Challenges and Opportunities for Empowerment V1. 2020, E-ISSN: 2222-6990 @ 2020 HRMARS

The extension of cohesion theories involves emotional dimensions with a set of attitudes like solidarity, trust, a sense of belonging, togetherness, membership, and the member's willingness to participate for equal benefits. Bonding between individuals is created once they feel connected through group feeling, frequent social interactions, social attraction, social capital, and task commitment or interdependence (Khaldun, 1969; Le Bon, 1896; Lewin, 1943; Deutsch, 1949; Festinger, 1954; French, 1956; Homans, 1958; Bourdieu, 1986; Hogg, 1992; Tajfel \& Turner, 1979; Lawler \& Yoon, 1993). Friedkin (2004) highlighted that social cohesion has no definite definition due to the complex system of various disciplines that studies the concept like sociology, social psychology, mental health, public health.

The studies on social cohesion have revolved around three methodological approaches: empirical, experimental, and social network analysis (Bruhn, 2009). Although the concept has a multidisciplinary approach, Friedkin (2004) emphasized that it is not important whether social cohesion is conceptualized according to the individual's membership duration or according to the individual's desire to maintain membership. He accentuated that based on past theories, it is important to note that there is a causal relationship between the two or more variables. Hence, Table 1 will explain the process of extension, intension, and evolution of theories related to the micro-macro interaction of social cohesion.

Table 1. Interrelated theoretical assumptions on the concept of social cohesion.

\begin{tabular}{|c|c|c|c|}
\hline $\begin{array}{l}\text { Author (s) } \\
\text { and year }\end{array}$ & Theory & Definition & Dimensions involved \\
\hline $\begin{array}{l}\text { Ibn Khaldun } \\
\text { (1377) }\end{array}$ & Asabiyah theory & $\begin{array}{l}\text { It is the notion social solidarity with an } \\
\text { emphasis on unity, group feeling and } \\
\text { sense of shared purpose, and social } \\
\text { cohesion within the context of } \\
\text { tribalism and clannism. It is known to } \\
\text { be a fundamental bond of human } \\
\text { society and the basis motive force of } \\
\text { nomadic history. }\end{array}$ & $\begin{array}{ll}\text { - } & \text { Social bond } \\
\text { - } & \text { Cultural bond } \\
\text { - } & \text { Social solidarity } \\
\text { - } & \text { Cohesion }\end{array}$ \\
\hline $\begin{array}{l}\text { Durkheim } \\
\text { (1893) }\end{array}$ & $\begin{array}{l}\text { Social integration } \\
\text { theory }\end{array}$ & $\begin{array}{l}\text { It is believed that society exerted a } \\
\text { powerful force on individuals. It } \\
\text { asserts that people's norms, beliefs, } \\
\text { and values make up a collective } \\
\text { consciousness, or a shared way of } \\
\text { understanding and behaving in the } \\
\text { world. As a result, collective } \\
\text { consciousness binds individuals } \\
\text { together and creates social } \\
\text { integration. }\end{array}$ & $\begin{array}{ll}\text { - } & \text { Organic solidarity } \\
\text { - } & \text { Mechanical } \\
\text { - } & \text { Solidarity } \\
\text { - } & \text { Cocial interactions } \\
\text { - } & \text { Monsciousness } \\
\text { - } & \text { Moral density }\end{array}$ \\
\hline $\begin{array}{ll}\text { Le } & \text { Bon } \\
(1896) & \end{array}$ & Contagion theory & $\begin{array}{l}\text { It is the solidarity of the crowd due to } \\
\text { its uniformity of action or collective } \\
\text { behavior which explains that the } \\
\text { crowd can cause a hypnotic impact on }\end{array}$ & $\begin{array}{ll}\text { - } & \text { Hypnotic } \\
\text { influence } \\
\text { - } \\
\text { - } & \text { Contental unity } \\
\end{array}$ \\
\hline
\end{tabular}


INTERNATIONAL JOURNAL OF ACADEMIC RESEARCH IN BUSINESS AND SOCIAL SCIENCES

Vol. 10, No. 15, Youth and Community Wellbeing: Issues, Challenges and Opportunities for Empowerment V1. 2020, E-ISSN: 2222-6990 @ 2020 HRMARS

\begin{tabular}{|c|c|c|c|}
\hline & & $\begin{array}{l}\text { individuals which, in turn, is largely } \\
\text { due to its anonymity and contagion. }\end{array}$ & \\
\hline $\begin{array}{l}\text { Lewin } \\
(1943)\end{array}$ & $\begin{array}{l}\text { Group dynamics } \\
\text { theory }\end{array}$ & $\begin{array}{l}\text { It is the degree of interdependence } \\
\text { between group members depending } \\
\text { on the size, organization, and intimacy } \\
\text { of the group. The process is affected } \\
\text { by the way groups and individuals } \\
\text { think and feel, and their interaction } \\
\text { especially within a group } \\
\text { environment. }\end{array}$ & $\begin{array}{ll}\text { - } & \text { Positive } \\
\text { interpersonal } \\
\text { interaction } \\
\text { - Uniformity } \\
\text { - Cohesiveness } \\
\text { - Group norms } \\
\text { - Trust } \\
\end{array}$ \\
\hline $\begin{array}{l}\text { Deutsch } \\
\text { (1949) }\end{array}$ & $\begin{array}{l}\text { Theory of } \\
\text { cooperation and } \\
\text { competition }\end{array}$ & $\begin{array}{l}\text { It is the belief that cooperation is } \\
\text { better than competition upon small- } \\
\text { group functioning. It asserts that } \\
\text { cooperation is to the group member's } \\
\text { mutual benefit, resulting in a win-win } \\
\text { situation. Group members rewarded } \\
\text { on a cooperative basis are more } \\
\text { cohesive than members rewarded on } \\
\text { a competitive basis. }\end{array}$ & $\begin{array}{ll}\text { - } & \text { Network } \\
\text { - } & \text { Colationship } \\
\text { - } & \text { Cooperation } \\
\text { - } & \text { Conflict } \\
\text { - } & \text { Negotiation }\end{array}$ \\
\hline $\begin{array}{l}\text { Festinger, } \\
\text { Schachter, } \\
\text { and Back } \\
(1950)\end{array}$ & $\begin{array}{l}\text { Group } \\
\text { cohesiveness } \\
\text { theory }\end{array}$ & $\begin{array}{l}\text { It is the attractiveness to people which } \\
\text { have the best care within the group } \\
\text { and attractiveness to the group. It } \\
\text { asserts that Members of strongly } \\
\text { cohesive groups are more inclined to } \\
\text { participate readily and to stay with the } \\
\text { group. }\end{array}$ & $\begin{array}{l}\text { - } \text { Social relations } \\
\text { - } \text { Task commitment } \\
\text { - } \text { Perceived unity } \\
\text { - Emotions } \\
\text { - Attraction } \\
\text { - } \text { Group pride } \\
\text { - Interpersonal } \\
\text { attraction } \\
\end{array}$ \\
\hline $\begin{array}{l}\text { French } \\
\text { (1956) }\end{array}$ & $\begin{array}{l}\text { Theory of social } \\
\text { power }\end{array}$ & $\begin{array}{l}\text { It is the potential for social influence a } \\
\text { person has among their peers and } \\
\text { within the society defined by the five } \\
\text { sources of power for changing } \\
\text { conditions inside or outside a social } \\
\text { group. }\end{array}$ & $\begin{array}{ll}\text { - } & \text { Reward } \\
\text { - } & \text { Coercion } \\
\text { - } & \text { Legitimate } \\
\text { - } & \text { Expert } \\
\text { - } & \text { Referent }\end{array}$ \\
\hline $\begin{array}{l}\text { Homans } \\
\text { (1958) }\end{array}$ & $\begin{array}{l}\text { Social exchange } \\
\text { theory }\end{array}$ & $\begin{array}{l}\text { It is the weight of costs against } \\
\text { benefits while forming a relationship. } \\
\text { It asserts that relationship } \\
\text { commitments form because of self- } \\
\text { interest and interdependence, social } \\
\text { exchanges produce emotions (or } \\
\text { feelings), and under certain } \\
\text { conditions, people associate their } \\
\text { individual feelings with their }\end{array}$ & $\begin{array}{l}\text { - Individualism or } \\
\text { - } \text { self-interest } \\
\text { - } \text { Interdependence } \\
\text { - } \text { Rests } \\
\text { - Reciprocity }\end{array}$ \\
\hline
\end{tabular}


INTERNATIONAL JOURNAL OF ACADEMIC RESEARCH IN BUSINESS AND SOCIAL SCIENCES

Vol. 10, No. 15, Youth and Community Wellbeing: Issues, Challenges and Opportunities for Empowerment V1. 2020, E-ISSN: 2222-6990 @ 2020 HRMARS

\begin{tabular}{|c|c|c|c|}
\hline & & $\begin{array}{l}\text { relationship or shared group } \\
\text { affiliation. }\end{array}$ & \\
\hline $\begin{array}{l}\text { Thibaut and } \\
\text { Kelley } \\
\text { (1959) }\end{array}$ & $\begin{array}{l}\text { Interdependence } \\
\text { theory }\end{array}$ & $\begin{array}{l}\text { It is the expectation of the kinds of } \\
\text { outcomes a person expects to receive } \\
\text { in a relationship. It asserts that the } \\
\text { rewards and costs associated with a } \\
\text { person's interpersonal relationship } \\
\text { will influence their expectation so they } \\
\text { can evaluate the outcome of their } \\
\text { relationship as either positive or } \\
\text { negative. }\end{array}$ & $\begin{array}{l}\text { - } \text { Emotional reward } \\
\text { - } \text { Social reward } \\
\text { - Instrumental } \\
\text { reward } \\
\text { - Opportunity } \\
\text { reward }\end{array}$ \\
\hline $\begin{array}{l}\text { Bormann } \\
(1972)\end{array}$ & $\begin{array}{l}\text { Symbolic } \\
\text { Convergence } \\
\text { Theory }\end{array}$ & $\begin{array}{l}\text { It is a process through which } \\
\text { collectives create and share a } \\
\text { consciousness and develop a common } \\
\text { symbolic reality. It asserts that once a } \\
\text { group consciousness or mutual } \\
\text { understanding is achieved, it results in } \\
\text { group's cohesiveness, consisting of } \\
\text { shared emotions, motives, and } \\
\text { meanings where they no longer think } \\
\text { in terms of "I" or "me" but in terms of } \\
\text { "us" and "we." }\end{array}$ & $\begin{array}{l}\text { - } \text { Shared group } \\
\text { consciousness } \\
\text { - Common } \\
\text { symbolic reality }\end{array}$ \\
\hline $\begin{array}{l}\text { Tajfel and } \\
\text { Turner } \\
\text { (1979) }\end{array}$ & $\begin{array}{l}\text { Social identity } \\
\text { theory }\end{array}$ & $\begin{array}{l}\text { It is the perception of self and others } \\
\text { based on the social group that the } \\
\text { person belongs to. It asserts that } \\
\text { people develop a sense of personal } \\
\text { identity through reliance upon factors } \\
\text { that make them unique and possess } \\
\text { multiple identities associated with } \\
\text { their affiliated group memberships. }\end{array}$ & $\begin{array}{l}\text { - Social } \\
\text { categorization } \\
\text { - Social } \\
\text { identification } \\
\text { - Intergroup } \\
\text { comparison }\end{array}$ \\
\hline $\begin{array}{l}\text { Bourdieu } \\
\text { (1986) }\end{array}$ & $\begin{array}{l}\text { Social } \\
\text { theory }\end{array}$ & $\begin{array}{l}\text { It is about the value of a durable } \\
\text { network of institutionalized } \\
\text { relationships of mutual acquaintance } \\
\text { or recognition, connections, and } \\
\text { provides each member with the } \\
\text { backing of collectivity. It asserts that } \\
\text { individuals invest in social relations } \\
\text { with the aim of economic, social and } \\
\text { symbolic "profit" that follows from } \\
\text { belonging to the association, leading } \\
\text { to the growth of solidarity. }\end{array}$ & $\begin{array}{ll}\text { - } & \text { Social } \\
\text { connections } \\
\text { - } & \text { Social networks } \\
\text { - } & \text { Social support } \\
\text { - } & \text { Group } \\
\text { membership }\end{array}$ \\
\hline Hogg (1992) & $\begin{array}{l}\text { Self-categorization } \\
\text { theory }\end{array}$ & $\begin{array}{l}\text { It is the process of people forming } \\
\text { cognitive representations of }\end{array}$ & $\begin{array}{ll}\text { - } & \text { In-group } \\
\text { - } & \text { Out-group }\end{array}$ \\
\hline
\end{tabular}


INTERNATIONAL JOURNAL OF ACADEMIC RESEARCH IN BUSINESS AND SOCIAL SCIENCES

Vol. 10, No. 15, Youth and Community Wellbeing: Issues, Challenges and Opportunities for Empowerment V1. 2020, E-ISSN: 2222-6990 @ 2020 HRMARS

\begin{tabular}{|c|c|c|c|}
\hline & & $\begin{array}{l}\text { themselves and others in relation to } \\
\text { different social groups and focuses } \\
\text { more on uncertainty reduction rather } \\
\text { than self-esteem as a motive. It } \\
\text { asserts that people place themselves } \\
\text { and others into social categories } \\
\text { based on in-group and out-group } \\
\text { attributes, the process shapes their } \\
\text { attitudes, emotions, and behaviors. }\end{array}$ & $\begin{array}{ll}\text { - } & \text { Perceived fit } \\
\text { - } & \text { Perceived } \\
& \text { readiness }\end{array}$ \\
\hline $\begin{array}{l}\text { Lawler and } \\
\text { Yoon (1993, } \\
\text { 2002) }\end{array}$ & $\begin{array}{l}\text { Relational } \\
\text { cohesion theory }\end{array}$ & $\begin{array}{l}\text { It explains how and when people who } \\
\text { are exchanging things of value } \\
\text { develop stable and cohesive } \\
\text { relationships. It asserts that people } \\
\text { tend to interact and commit to the } \\
\text { group because they get something } \\
\text { they value or want from others. }\end{array}$ & $\begin{array}{l}\text { - Interdependence } \\
\text { - Social exchanges } \\
\text { - Predictability } \\
\text { - Positive emotions } \\
\text { - Group cohesion } \\
\text { - Commitment }\end{array}$ \\
\hline
\end{tabular}

Based on Table 2, the concept of cohesion gradually evolved from clannism to a collective consciousness of individuals attracted to one another in a group or group cohesion. Scholars in these eras started using the term group cohesion to describe social and dynamic process that involves group members who are willing to stick together and remain in the group that has mutual attraction. Overall, the concept of social cohesion during this era resides when individuals identify themselves as members of a group that they consider as in-groups as opposed to out-groups, however, the mechanism of group cohesion only applies at a group level phenomenon and not towards the mass. Then again, recent scholars have argued that where there is a group, there must be cohesion.

Table 2. The characteristics of group cohesion.

"a shared way of understanding and behaving in the world that binds individuals together and creates social integration"

- Durkheim (1893)

"the share of personal and enduring relationships"

- Cooley (1902)

"group identification and emotional ties"

- Freud (1921)

"collective individuals with common mode of feeling and reciprocal influence"

- MacDougall (1921) (cited in Bruhn, 2009)

"attraction and repulsion among group members"

- Moreno (1934)

"interdependence and intimacy of group members"

- $\quad$ Lewin (1943)

"situation where cooperation is to member's mutual benefit"

- Deutsch (1949) 
INTERNATIONAL JOURNAL OF ACADEMIC RESEARCH IN BUSINESS AND SOCIAL SCIENCES

Vol. 10, No. 15, Youth and Community Wellbeing: Issues, Challenges and Opportunities for Empowerment V1. 2020, E-ISSN: 2222-6990 @ 2020 HRMARS

"membership continuity - the cement that binds together group members to remain in the group"

- Festinger, Schachter, \& Back (1950)

"when group members accept and conform to group norms"

- $\quad$ Cartwright \& Zander (1960)

"the resultant forces which are acting on the members to stay in a group or the attraction of membership in a group for its members"

- $\quad$ Back (1951)

"the power of groups to generate conformity and willingness to compromise"

- Asch (1952)

"the resistance of a group to disruptive forces"

- Gross \& Martin (1952)

"the attractiveness of the group, which is the pooled effect or the average of the individual members' attraction-to-group or their wish to remain in the group"

- Israel (1956)

"a property that is inferred from the number and strength of mutual positive attitudes among group members"

- $\quad$ Lott \& Lott (1960)

"the resultant of all forces acting on all the members to remain in the group"

- Cartwright (1968)

"cooperative interdependence in the pursuit of shared goals"

- Sherif \& Sherif (1969)

"consensus among group members"

- Friedkin (1984)

"a sense of belonging and feelings of morale"

- $\quad$ Bollen \& Hoyle (1990)

"attraction and bonding, and self-disclosure and feedback"

- Braaten (1991)

"a measure of the willingness of people to stay in the community"

- Robbins (1993)

"a set of social processes that help instil in individuals the sense of belonging to the same community and the feeling that they are recognized as members of the community

- Commissariat Général du Plan, 1997 (quoted in Jenson, 1998)

"dynamic process through which group members stick together and remain united" Carron \& Hausenblas (1998)

Starting from 2000 onwards, the concept of social cohesion has become more specific and specialized (refer to Table 3). Although the concept has become more specific and specialized, the classical idea that social cohesion is the "field of forces" of conditions (direct or indirect attributes) and the causal system that determines a person's membership attitudes and behaviors still remains the same. 
INTERNATIONAL JOURNAL OF ACADEMIC RESEARCH IN BUSINESS AND SOCIAL SCIENCES

Vol. 10, No. 15, Youth and Community Wellbeing: Issues, Challenges and Opportunities for Empowerment V1. 2020, E-ISSN: 2222-6990 @ 2020 HRMARS

Table 3: Refined characteristics of social cohesion.

"the strength of psychological link among members, and the attraction of community to members"

- Younglin \& Maryam (2001)

"the degree to which people respond cooperatively to achieve their valued outcomes and to deal with the political, economic, social, or environmental stresses that influence them"

- $\quad$ Reimer (2002)

"a sense of responsibility and trust"

- Figueroa, Kincaid, Rani, \& Lewis (2002)

"the paths that link members are the social glue that hold them together"

- Moody \& White (2003)

"mutually supportive community of free individuals pursuing these common goals by democratic means"

- $\quad$ European Committee for Social Cohesion (2004) (cited in Figueroa et al., 2002)

"the construction of shared values and communities of interpretation engaged in a common enterprise to address common challenges, and the reduction of inequality in wealth and income"

- Jupp, Nieuwenhuysen \& Dawson (2007)

"the bond that brings people together"

- Bruhn (2009)

"a cohesive society will work towards the well-being of all its members, minimizing disparities and avoiding marginalization between different groups, fighting discrimination, exclusion and excessive inequalities"

- Organization for Economic Co-operation and Development (2011)

"a sum of the positive forces that works towards the well-being of all members, fights exclusion and marginalization, creates a sense of belonging, promotes trust, and offers its members the opportunity of upward mobility

- Woolcock (2011)

"a form of self-disclosure, member acceptance, empathy, roles, social trust, and social interaction"

- Bolong (2011)

"a measure of predictability to interactions across people and groups, which in turn provides incentives for collective action"

- Social Development Department, World Bank (2012)

"the quality of social cooperation and togetherness of a collective, defined in geo-political terms, that is expressed in the attitudes and behaviours of its members"

- Dragolov, Koch, \& Larsen (2018)

Overall, based on the tables above it can be synthesized that there are four main dimensions to measure the level of social cohesion; Sense of togetherness, Sense of belonging, Social trust, and Social interaction. 
INTERNATIONAL JOURNAL OF ACADEMIC RESEARCH IN BUSINESS AND SOCIAL SCIENCES

Vol. 10, No. 15, Youth and Community Wellbeing: Issues, Challenges and Opportunities for Empowerment V1. 2020, E-ISSN: 2222-6990 @) 2020 HRMARS

\section{The Importance of Social Cohesion}

Social cohesion is a social phenomenon that attracts members to one another and to a group. Cartwright (1968) stated in his theory that social cohesion is different from integration as it is the sum of the positive forces of different individuals have in each member's life-space and this it is the consequence of different forces acting on all the members to remain within the group. It is considered as a crucial element of a successful society since it enhances coordination and productivity between individuals. Social cohesion can instill a sense of belonging and oneness, when individuals identify with, and classify themselves into a social category. Consequently, as individuals self-identify themselves into a social category it leads to in-group favoritism and result in commitment to the group, product or service (Hu, Zhang, \& Wang, 2017).

Instilling a sense of social cohesion among community members can create a thriving place in which a fear of difference is replaced by a shared set of values and a shared sense of purpose and belonging, higher trust, better social and emotional support, resolve tensions, and bringing people together (Dragolov et al., 2018). Unfortunately, rising income inequality (Wilkinson \& Pickett, 2009; Burhan et al, 2015; Mohamad et al., 2019), unemployment and crime (Jenson, 1998; Shawkat, 2010; Smith, 2010), a rise of a more individualized generation (Putnam, 2000), anxiety, uncertainty, and ethnocentrism (Levin, Taylor, \& Caudle, 2007; Logan, Steel, \& Hunt, 2014) have been the cause of the decline in social cohesion. Mennis, Dayanim, and Grunwald (2013), and Hamid, Marzuki, Ahmad, and Ishak (2016) claimed that an increase in inter-ethnic neighborhood lowers participation in social activities due to poor cooperation and low sense of social cohesion. These are the characteristics of being uncertain about others, such uncertainty stems from an antiquated understanding of diversity.

Nowadays, that old notion of diversity has changed after decades of incoming immigrations, which changed the nature of multi-ethnic neighborhoods today. One aspect of cohesiveness is based on virtual community members' liking for one another and on their desire to be in the group and share the same goal. It is an important aspect of being a part of an online community and feel like they belong. Plus, to successfully build and maintain a collective community remains a challenge, especially when it involves emotional aspects such as trust (Powell, Piccoli, \& Ives, 2004; Lawler, and Yoon, 2014; Sarwari, Wahab, Said, \& Aziz, 2018).

Trust is an important emotional factor that may affect the level of social cohesion; Lawler, Thye, and Yoon (2000) explained in their theory of relational cohesion that emotion plays an important role in enhancing social cohesion. The theory has gone through several studies to show how and when positive emotional processes could generate commitment to relationship with others and the members within their group based on the frequency of their interaction and shared focus. Huang, Cheng, Huang \& Teng (2018) further argues that frequent social interaction through SNS produces positive emotions that could enhance their commitment and ultimately encourages them to remain in the relationship.

\section{Interaction within Virtual Communities}

Since the emergence of the Internet, virtual communities have also become a popular phenomenon. Virtual communities affect the social interaction of people and shape different areas of their life, including their working life and their leisure time as well as enabling members to start new friendships, learn, and form opinions and exchange information on products (Bagozzi \& Dholakia, 2002). Virtual communities are an important resource for people with various interests, 
INTERNATIONAL JOURNAL OF ACADEMIC RESEARCH IN BUSINESS AND SOCIAL SCIENCES

Vol. 10, No. 15, Youth and Community Wellbeing: Issues, Challenges and Opportunities for Empowerment V1. 2020, E-ISSN: 2222-6990 @ 2020 HRMARS

goals, and needs (Jin, Park, \& Kim, 2010). With different cultural preferences, other approaches of socialization can be applied; Powell et al. (2004): Madell and Muncer (2007): and Tomasello, Lee \& Baer (2010), all claimed that social bonding can be done partially via electronic communication tools such as SNS.

In 2017, Chung, Tyan, and Chung argued that virtual communities and social networks have verified the crucial role of community identification of members in showing positive outcomes such as consumption behaviors, generating positive word-of-mouth, and continuous usage intention. Previously, Walton and Hardebeck (2016) highlighted the fact that to understand the decline in social cohesion, one must first understand the urbanization processes. They further insinuated the key perspective that threatens social cohesion in neighborhoods is due to the social disorganization perspective, which says racial heterogeneity hampers any form of communication and limits the achievement of common goals.

Tobin, Vanman, Verreynne and Saeri's (2014), and Sahharon, Bolong, Omar, and Shaffril (2018) study on Facebook use helped examine the feeling of meaningful existence as an outcome of Facebook functionality use. Sahharon et al. (2018) highlighted that the most used Facebook functions were group, conversation, sharing, identity and reputation to sustain their interpersonal relationship between close and distant friends. Being a member of a social group is a psychological state in which members feel a sense of togetherness and a sense of belonging. Favoritism towards an in-group is purely an interpersonal interaction, which involves people relating entirely as individuals, social ingroup members for example, feel a sense of engagement with members whom they share similar traits (Bolong, 2011).

Much interdependence could lead to a collaborative social interaction, communication, similarity and influence between individuals. However, a purely intergroup interaction causes the members to relate entirely as representatives of their groups (Kelley, Holmes, Kerr, Reis, Rusbult \& Van Lange, 2003). Overall, the mechanisms of social connection provided by SNS such as Facebook, Twitter, YouTube, blogs, and webpages have effects that are either favorable or unfavorable for social cohesion. It seems that these internet capabilities have the potential for working in both directions, which can be both undermining and enhancing social cohesion. Hence, as highlighted by Durkheim and Tönnies, SNS can become a contemporary alternative to the face-to-face relationships (Pahnila \& Warsta, 2012; Whitaker, 2013; Ellison \& Boyd, 2013).

\section{Methodology}

In this study, a multi-stage cluster sampling is employed. First, all states were grouped according to their zones (Southern, Northern, Central, East Coast, and Borneo). Second, a state was selected to represent the selected zone. Third, two parliamentary/district areas were selected randomly to represent urban and rural. Fourth, a total of 100 SNS' users were selected as respondents to represent an area. In total, about 600 youths were involved in the study. Both urban and rural locations were chosen for generalization. The locations chosen for this study are Penang (Northern zone), Selangor (central zone), Johor (Southern zone), Terengganu (East Coast zone), and both Sabah and Sarawak to represent the Borneo.

The subject of study is multi-ethnic youths in Malaysia ranging from 15 to 40 years old and frequent several SNS. This study uses purposive sampling to find eligible respondents who meet the criteria of the study. Based on the ethnic group composition in 2017, there are $68.8 \%$ Bumiputera, 
INTERNATIONAL JOURNAL OF ACADEMIC RESEARCH IN BUSINESS AND SOCIAL SCIENCES

Vol. 10, No. 15, Youth and Community Wellbeing: Issues, Challenges and Opportunities for Empowerment V1. 2020, E-ISSN: 2222-6990 @) 2020 HRMARS

23.2\% Chinese, and 7\% Indian out of the total population of citizens (Mahidin, 2017). The ratio of 100 respondents for each zone is sorted according to race/area (refer to Table 4). After being identified to be eligible to answer the survey, the respondent was given a questionnaire to answer.

Table 4. Ratio according to race and area.

\begin{tabular}{|l|l|l|l|}
\hline \multirow{2}{*}{ Race } & Area & \multirow{2}{*}{ TOTAL } \\
\cline { 2 - 4 } & Urban & Rural & \\
\hline Bumiputera & 35 & 35 & 70 \\
\hline Chinese & 12 & 12 & 24 \\
\hline Indian & 3 & 3 & 6 \\
\hline Total & 50 & 50 & 100 \\
\hline
\end{tabular}

\section{Social Cohesion Measurement}

There are four dimensions to measure the respondent's sense of social cohesion within their virtual communities; sense of togetherness, sense of belonging, social trust, and social interaction. In total there are 24 items to measure the level of social cohesion among Malaysian virtual youth communities. All items are measured on a 7-point Likert-type scale level of agreement. The 7-point level of agreement ranges from 1 indicating strongly disagree to 7 indicating strongly agree. Based on this scale, the highest average score reflects a strong sense of social cohesion and otherwise the lowest average score reflects a weak sense of social cohesion among virtual communities' members.

The items for social cohesion have been modified from the original list of questions by Figueroa et al. (2002) and Bolong (2006). According to Figueroa et al. (2002), there are six related social and cognitive dimensions (i.e. sense of belonging, feelings of morale, goal consensus, trust, reciprocity, and network cohesion) of social cohesion that act on members of a group or community to remain within the group and actively contribute to it. In a cohesive group, members would want to belong to the group, like one another, get along, be loyal to each other, and cooperate in the pursuit of group goals. Figueroa et al. believed that social cohesion is an important antecedent and consequence of a successful collective action.

The first dimension, a sense of togetherness is measured on whether the respondents felt like they are part of their virtual communities, whether their SNS profile belongs to them, whether they put themselves as a part of the virtual community where they know about other people, whether they attempt to achieve a common goal and understanding, and whether they want to leave the virtual community.

The second dimension, a sense of belonging is measured on the extent to which individual members felt as if they are an important part of the community, whether they are happy and satisfied to be a part of the virtual community, whether the virtual community is one of the best virtual community they have joined, whether they want to work with the same individuals in realizing their community projects in the future, whether help is mutual, and whether others were willing to share responsibilities in order to create a better environment.

The third dimension, social trust is measured on the level of trust between youths in their virtual communities, whether they think their virtual community members would think that they have to share the benefits obtained from the output of their work, their beliefs whether doing a project in their virtual community is important, and whether youths are comfortable in giving 
INTERNATIONAL JOURNAL OF ACADEMIC RESEARCH IN BUSINESS AND SOCIAL SCIENCES

Vol. 10, No. 15, Youth and Community Wellbeing: Issues, Challenges and Opportunities for Empowerment V1. 2020, E-ISSN: 2222-6990 @ 2020 HRMARS

responsibilities knowing that their virtual community members can be trusted in realizing a planned project.

The fourth dimension, social interaction is measured on whether the respondents will share responsibilities with each other in their virtual community, whether their virtual community members are convincing or take advantage of one another, and their agreement on fulfilling their obligations towards their virtual community knowing the others would do the same.

\section{Findings and Discussion}

The pattern of SNS usage presents the years of experience for SNS usage, and the frequency of SNS usage among youths in Malaysia. As shown in Table 6 (Appendix 1), 80.7\% of Malaysian youths have used SNS between 11 to 20 years while $18.7 \%$ had more than 20 years of experience. On average, Malaysian youths had 8.39 years of SNS usage experience. The highest downloaded and used SNS app was WhatsApp $(n=296)$, followed by YouTube $(n=273)$, and Instagram $(n=248)$. Meanwhile, the least downloaded and used app was WeChat $(n=89)$.

Pertaining to the frequency of SNS app usage, the respondents frequently opened WhatsApp $(M=17.27)$, Instagram ( $M=9.45)$, and YouTube $(M=5.28)$. Through this category of SNS usage, it was a mix of categories because WhatsApp provides a chatting platform to maintain interpersonal relationship, while Instagram provides visual platform with interactions through comments and DMs, while YouTube provides a video platform with comments and likes.

Approximately, Malaysian youths spent less than one hour per SNS usage. For example, since YouTube is a video platform, they spent nearly an hour on it compared to Facebook and Instagram. The average time they spent of chatting apps depends on how many friends they have as members; these youths spent about 13 minutes on WhatsApp per use, 5 minutes on Telegram per use, and 3 minutes on WeChat per use. This finding was useful enough to understand that these users would use several channels to sustain their relationships and flow of communication.

\section{Social Cohesion in Virtual Community}

The overall assessment of social cohesion is measured based on the mean score of the added four dimensions based on the average classification of the seven-point scale. The percentages of total respondents per level indicate the intensity of the respondents is in the measured level of social cohesion.

Table 5. Distribution of Malaysian youth by Level of Cohesiveness.

\begin{tabular}{|l|l|l|l|l|l|}
\hline \multirow{2}{*}{$\begin{array}{l}\text { Cohesiveness } \\
\text { Dimensions }\end{array}$} & \multicolumn{2}{|l|}{ Level by range } & $\begin{array}{l}\text { Overall } \\
\text { Mean }\end{array}$ & $\begin{array}{l}\text { Standard } \\
\text { Deviation }\end{array}$ \\
\cline { 2 - 6 } & $\begin{array}{l}\text { Low (1.00- } \\
\mathbf{3 . 0 0}\end{array}$ & $\begin{array}{l}\text { Moderate } \\
\mathbf{( 3 . 0 1 - 5 . 0 0}\end{array}$ & $\begin{array}{l}\text { High (5.01- } \\
\mathbf{7 . 0 0}\end{array}$ & & \\
\hline $\begin{array}{l}\text { Sense of } \\
\text { togetherness }\end{array}$ & $60(10.0 \%)$ & $398(66.3 \%)$ & $142(23.7 \%)$ & 4.354 & 1.034 \\
\hline Sense of belonging & $54(9.0 \%)$ & $389(64.8 \%)$ & $157(26.2 \%)$ & 4.437 & 1.031 \\
\hline Social trust & $78(13.0 \%)$ & $405(67.5 \%)$ & $117(19.5 \%)$ & 4.298 & 1.046 \\
\hline Social interaction & $90(15.0 \%)$ & $401(66.8 \%)$ & $109(18.2 \%)$ & 4.189 & 1.048 \\
\hline
\end{tabular}




\section{Sense of Togetherness}

Based on the data in Table 5, more than half of Malaysian virtual youth communities (66.3\%) had a moderate level of sense of togetherness, while only $23.7 \%$ had a high sense of togetherness and only $10.0 \%$ had a low level of togetherness in their virtual communities. Although the sense of togetherness was only moderate among virtual youth communities, the finding illustrates how SNS made them feel like a member of the virtual communities despite being physically apart from each other. These youths acknowledged that despite the ethnicity and cultural differences, they felt that the virtual communities belong to them without prejudice.

On average, they refused to leave their virtual communities because they want to show that they felt cohesive with other members in the communities. Feeling of cohesiveness arise due to the virtual communities' environment, which were proven to support and foster mutual understanding. As a result, findings from this study supported the Asabiyah theory, which expresses the notion of social solidarity with an emphasis on unity, group feeling and sense of shared purpose, and social cohesion within the context of tribalism and clannism. Therefore, even within the context of virtual communities, the concept of Asabiyah theory introduced by Ibn Khaldun (1377) is still relevant to this day.

\section{Sense of Belonging}

Several studies in the past have concluded (about 3 to 5 scholars who studied sense of belonging) that virtual communities within SNSs are only temporary and cannot last long because their members had the option whether to remain or to leave the group without permission or feeling of guilt towards other members. However, these studies did not convey the sense of belonging among the increasingly active SNS usage among youths as shown in Table 5. Findings from this study contradicts past findings. It was found that $64.8 \%$ of virtual youth communities in Malaysia had a moderate level of sense of belonging, $26.2 \%$ yielded a high sense of belonging, and only $9.0 \%$ yielded a low sense of belonging.

The moderate sense of belonging among virtual youth communities implied that the members who used various SNS channels as a medium to interact are prone to be cohesive. It can be concluded that youths are happy to be part of their virtual communities and they are willing to help each other in likelihood of future problems. In fact, the youths in this study were satisfied to be part of their virtual communities, thus they are bonded by their sense of belonging. Therefore, there was no such member who would leave their communities. As argued by Festinger et al. (1950) in their group cohesiveness theory, it is the attractiveness to people that have the best care within the group and attractiveness to the group that made them refuse to leave. It asserts that members of a highly cohesive groups are more inclined to participate readily and to stay with the group.

\section{Social Trust}

Interactions through SNS has the potential to effectively convey verbal, non-verbal, non-vocal messages. Undeniably, SNS platforms are increasingly rich in delivering synchronized and asynchronous messages but nowadays there are still miscommunications and misunderstandings between SNS users who are complete strangers from different races, to the extent that occurrences of trust issues still remain within the virtual communities. This study clearly shows that the majority $67.5 \%$ of virtual youth communities in Malaysia had a moderate level of social trust among their 
INTERNATIONAL JOURNAL OF ACADEMIC RESEARCH IN BUSINESS AND SOCIAL SCIENCES

Vol. 10, No. 15, Youth and Community Wellbeing: Issues, Challenges and Opportunities for Empowerment V1. 2020, E-ISSN: 2222-6990 @) 2020 HRMARS

virtual communities' members (refer to Table 5), 19.5\% highly trusted their virtual communities' members, and about $13.0 \%$ had low sense of social trust with their virtual communities' members.

Woolcock (2011) and Bolong (2011) argued that one of the key dimensions in determining a member's sense of cohesion is social trust. When mutual trust among members in the community is high, it enhances their sense of social cohesion. Although 405 out of the surveyed 600 youths in Malaysia had a moderate level of social trust, they still confide in their virtual community members by sharing their daily interests on SNS engagements. The act of sharing information or daily activities on SNSs is a form of self-disclosure, unless their social trust towards each other is high, self-disclosing daily activities is a rare sharing session between strangers. This study indicates that the youths involved in this study are still wary of sharing their daily activities and interest with other virtual community members. In fact, these youths were moderately confident in sharing mutual responsibilities during their interactions on SNSs, unless there is confiding elements that influences their trust, these youths are still on the brink to socially trust others would do the same.

\section{Social Interaction}

In relational cohesion theory, Lawler and Yoon $(1993,2002)$ explained how and when people who are exchanging things of value develop stable and cohesive relationships. It asserts that people tend to interact and commit to the group because they get something they value or want from others. This theory emphasized on social interaction not just on its intensity and quality on SNSs, but they focuses on whether the respondents will share responsibilities with each other in their virtual community, whether their virtual community members are convincing or take advantage of one another, and their agreement on fulfilling their obligations towards their virtual community knowing the others would do the same. Based on the data in Table 5, most of the youths in Malaysia had moderate level of social interaction (66.8\%), while the others yielded a high level of social interaction (18.2\%).

\section{Conclusion}

The concept of social cohesion has been gaining popularity among scholars since the era of Ibn Khaldun (1377) leading to recent years by Dragolov, Koch, \& Larsen (2018). These scholars have elaborated on the concept by introducing interrelated variables that make up the theory. During the synchronizing process of past theories, it was found that although the term differs according to scholars, the concept of social cohesion has consistent definitions and meanings. However, the elements of solidarity introduced by past scholars can be synthesized into four important dimensions to measure social cohesion. The four identified dimensions of social cohesion are sense of togetherness, sense of belonging, social trust, and social interaction.

Although it was established that social cohesion has four core dimensions, the measurement in these theories mainly refer to face-to-face interaction context within real life communities, thus leaving us to question the level of social cohesion among SNS users during their interactions on virtual communities. Overall, the majority of virtual youth communities who participated in this study had a moderate sense of togetherness, sense of belonging, social trust, and social interaction. These findings dismiss the concerns of social media scholar who claimed that virtual community members are unable to enhance their sense of social cohesion through SNS usage. The moderate level of social 
INTERNATIONAL JOURNAL OF ACADEMIC RESEARCH IN BUSINESS AND SOCIAL SCIENCES

Vol. 10, No. 15, Youth and Community Wellbeing: Issues, Challenges and Opportunities for Empowerment V1. 2020, E-ISSN: 2222-6990 @) 2020 HRMARS

cohesion also gives the impression that SNSs remain a potential medium for interaction to build a harmonious community although the society is still cynical about the negative influences of social media. It should be highlighted that SNS users should use the online platform wisely and positively in order to foster cohesion.

This study only revealed that Malaysian youth virtual communities yielded a moderate level of social cohesion when they use SNSs. Findings on the level of social cohesion alone is insufficient to understand the implications of SNS usage on the development of a model, thus there is a need for future study that focuses on the contributing factors of social cohesion to provide a better understanding on the issue of virtual communities, which is much discussed nowadays regarding Industrial Revolution 4.0.

\section{Acknowledgments}

This research was funded by a University Research Grant Scheme (GPB/2017/9543200) from Universiti Putra Malaysia, Selangor.

\section{References}

Aldous, J., Durkheim, E., \& Tonnies, F. (1972). An exchange between Durkheim and Tonnies on the nature of social relations, with an introduction by Joan Aldous. American Journal of Sociology, 77(6), 1191-1200.

Alesina, A., \& La Ferrara, E. (2000). Participation in heterogeneous communities. The quarterly journal of economics, 115(3), 847-904.

Asch, S. (1952). Social Psychology Prentice-Hall. Englewood Cliffs, NJ, 646.

Back, K. W. (1951). Influence through social communication. The Journal of Abnormal and Social Psychology, 46(1), 9.

Bagozzi, R. P., \& Dholakia, U. M. (2002). Intentional social action in virtual communities. Journal of interactive marketing, 16(2), 2-21.

Bollen, K. A., \& Hoyle, R. H. (1990). Perceived cohesion: A conceptual and empirical examination. Social forces, 69(2), 479-504.

Bolong, J. (2011). Minda Komuniti Maya. Universiti Kebangsaan Malaysia, Bangi.

Bormann, E. G. (1972). Fantasy and rhetorical vision: The rhetorical criticism of social reality. Quarterly journal of speech, 58(4), 396-407. Bourdieu, P., \& Richardson, J. G. (1986). Handbook of Theory and Research for the Sociology of Education. The forms of capital, 241258.

Braaten, L. J. (1991). Group cohesion: A new multidimensional model. Group, 15(1), 39-55.

Bruhn, J. (2009). The concept of social cohesion. In The group effect (pp. 31-48). Springer, Boston, MA.Burhan, N. A. S., Sidek, A. H., Kurniawan, Y., \& Mohamad, M. R. (2015). Has globalization triggered collective impact of national intelligence on economic growth?. Intelligence, 48, 152161.

Carron, A. V., \& Hausenblas, H. A. (1998). Group dynamics in sport. Morgantown, WV: Fitness Information Technology Cartwright, D. (1968). The nature of group cohesiveness. Group dynamics: Research and theory, 91, 109.

Cartwright, D., and Zander, A. (1960). Group Dynamics: Research and Theory (2nd ed.). Harper \& Row, Evanston. 
INTERNATIONAL JOURNAL OF ACADEMIC RESEARCH IN BUSINESS AND SOCIAL SCIENCES

Vol. 10, No. 15, Youth and Community Wellbeing: Issues, Challenges and Opportunities for Empowerment V1. 2020, E-ISSN: 2222-6990 @ 2020 HRMARS

Chung, N., Tyan, I., \& Chung, H. C. (2017). Social support and commitment within social networking site in tourism experience. Sustainability, 9(11), 2102. Cooley, C. H. (1992). Human nature and the social order. Transaction Publishers.

Deutsch, M. (1949). A theory of co-operation and competition. Human relations, 2(2), 129-152. DeVito, J. A. (2009). Human communication: the basic course. Array Boston.

Dragolov, G., Koch, M., \& Larsen, M. (2018). Level, Trend, and Profiles of Social Cohesion in Asia. What Holds Asian Societies Together? Insights from the Social Cohesion Radar, 69-95.

Durkheim, E. (1897). Suicide: A study in sociology. Free Press, New York.

Durkheim, E. (2014). The division of labor in society. Simon and Schuster. Ellison, N. B., \& Boyd, D. M. (2013). Sociality through social network sites. In The Oxford handbook of internet studies. (p. 151-172). Oxford University Press.

Festinger, L. (1954). A theory of social comparison processes. Human relations, 7(2), 117-140. Figueroa, M. E., Kincaid, D. L., Rani, M., \& Lewis, G. (2002). Communication for Social Change: an integrated model for measuring the process and its outcomes. Communication for Social Change working paper series, Working Paper Series: No.1. Rockfeller Foundation, New York. http://www.communicationforsocialchange.org/pdf/socialchange.pdf

Fischer, E., \& Reuber, A. R. (2011). Social interaction via new social media:(How) can interactions on Twitter affect effectual thinking and behavior?. Journal of business venturing, 26(1), 118.French Jr, J. R. (1956). A formal theory of social power. Psychological review, 63(3), 181. Freud, S. (1921). Group psychology and the analysis of the ego (Standard ed. 18). Hogarth, London.

Friedkin, N.E. (2004). Social cohesion. Annual Review Sociology, 30, 409-425.

Friedkin, N. E. (1984). Structural cohesion and equivalence explanations of social homogeneity. Sociological Methods \& Research, 12(3), 235-261. Gross, N., \& Martin, W. E. (1952). On group cohesiveness. American Journal of Sociology, 57(6), 546-564.Hamid, A. S. A., Marzuki, N. A., Ahmad, N. A., \& Ishak, M. S. (2016). Social capital and community cohesion: the constitution of community social capital in Malaysia. International Review of Management and Marketing, 6(8S).

Hogg, M. A. (1992). The social psychology of group cohesiveness: From attraction to social identity. Harvester Wheatsheaf and New York University Press.

Homans, G. C. (1958). Social behavior as exchange. American journal of sociology, 63(6), 597-606. Hu, M., Zhang, M., \& Wang, Y. (2017). Why do audiences choose to keep watching on live video streaming platforms? An explanation of dual identification framework. Computers in Human Behavior, 75, 594-606.Huang, H. C., Cheng, T. C. E., Huang, W. F., \& Teng, C. I. (2018). Who are likely to build strong online social networks? The perspectives of relational cohesion theory and personality theory. Computers in Human Behavior, 82, 111-123.

Israel, J. (1956). Self-evaluation and Rejection in Groups. Almqvist \& Wiksell.

Jarvenpaa, S. L., \& Leidner, D. E. (1999). Communication and trust in global virtual teams. Organization science, 10(6), 791-815. Jenson, J. (1998). Mapping social cohesion: The state of Canadian research. Canadian policy research networks. Jin, B., Park, J. Y., \& Kim, H. S. (2010). What makes online community members commit? A social exchange perspective. Behaviour \& Information Technology, 29(6), 587-599.Jupp, J. (2007). The quest for harmony. In Social cohesion in Australia. Cambridge University Press. 
INTERNATIONAL JOURNAL OF ACADEMIC RESEARCH IN BUSINESS AND SOCIAL SCIENCES

Vol. 10, No. 15, Youth and Community Wellbeing: Issues, Challenges and Opportunities for Empowerment V1. 2020, E-ISSN: 2222-6990 @ 2020 HRMARS

Lawler, E. J., Thye, S. R., \& Yoon, J. (2000). Emotion and group cohesion in productive exchange. American Journal of Sociology, 106(3), 616-657. Lawler, E. J., \& Yoon, J. (1993). Power and the emergence of commitment behavior in negotiated exchange. American Sociological Review, 465-481. Le Bon, G. (1896). The Crowd: A Study of the Popular Mind. Macmillan Company.

Levin, S., Taylor, P. L., \& Caudle, E. (2007). Interethnic and interracial dating in college: A longitudinal study. Journal of Social and Personal Relationships, 24(3), 323-341. Lewin, K. (1943). Psychology and the process of group living. The Journal of Social Psychology, 17(1), 113-131.Logan, S., Steel, Z., \& Hunt, C. (2014). A systematic review of effective intercultural communication in mental health. Cross-Cultural Communication, 10(5), 1-11.

Lott, B. E., \& Lott, A. J. (1960). The formation of positive attitudes toward group members. The Journal of Abnormal and Social Psychology, 61(2), 297. Madell, D. E., \& Muncer, S. J. (2007). Control over social interactions: an important reason for young people's use of the Internet and mobile phones for communication?. Cyberpsychology \& behavior, 10(1), 137-140.

Mahidin, M. U. (2017). Current population estimates, Malaysia, 2016-2017. Department of Statistics Malaysia.

Mansor, H. N. (2014). The role of school as community hub and its implications on promoting community cohesion towards sustainable communities (Doctoral dissertation, University of Salford).

Mohamad, N., Jusoh, H., \& Kassim, Z. (2019). Localizing of community resilience indicators for assessing the urban community resilience in Putrajaya, Malaysia. International Journal of Engineering and Advanced Technology, 8(5), 359-365.

Oliveri, F. (2005). Security and Social Cohesion: Deconstructing Fear (Of Others) By Going beyond Stereotypes. Trends in Social Cohesion (11). Council of Europe Publishing.

Organization for Economic Co-operation and Development. (2011). Development Co-operation Report 2011. https://www.oecd.org/dac/developmentco-operationreport2011.htm

Pahnila, S., \& Warsta, J. (2012). Assessing the Factors That Have an Impact on Stickiness in Online Game Communities. In PACIS (p. 106).

Pahl, R. E. (1991). The search for social cohesion: from Durkheim to the European Commission. European Journal of Sociology/Archives Européennes de Sociologie, 32(2), 345360. Powell, A., Piccoli, G., \& Ives, B. (2004). Virtual teams: a review of current literature and directions for future research. ACM SIGMIS Database: the DATABASE for Advances in Information Systems, 35(1), 6-36. Purohit, H., Ruan, Y., Fuhry, D., Parthasarathy, S., \& Sheth, A. P. (2014). On Understanding the Divergence of Online Social Group Discussion. ICWSM, 14, 396405.

Robbins, P. S. (1993). Organizational Behaviour-Concepts Controversies and Applications. PracticeHall.

Sahharon, H., Bolong, J., Omar, S. Z., \& Shaffril, H. A. M. (2018). Facebook usage pattern among rural youths of 1 Malaysia Wireless Village. International Journal of Academic Research in Business and Social Sciences, 8(3).

Saripudin, D., \& Komalasari, K. (2015). Living values education in school's habituation program and its effect on student's character development. The New Educational Review, 39(1), 51-62. 
INTERNATIONAL JOURNAL OF ACADEMIC RESEARCH IN BUSINESS AND SOCIAL SCIENCES

Vol. 10, No. 15, Youth and Community Wellbeing: Issues, Challenges and Opportunities for Empowerment V1. 2020, E-ISSN: 2222-6990 @ 2020 HRMARS

Sarwari, A. Q., Wahab, M. N., Said, M. H. M., \& Aziz, N. A. A. (2018). Assessment of the Characteristics of Interpersonal Communication Competence among Postgraduate Students from Different Cultures. Journal of Intercultural Communication, (47), 1-1.

Shawkat, A. R. (2010). Virtual Community as Platform Social Cohesion: A Case Study of Iraq (Doctoral dissertation, Universiti Utara Malaysia).

Sherif, M., \& Sherif, C. W. (1969). Ingroup and intergroup relations: Experimental analysis. Social psychology, 221-266.Smith, S. S. (2010). Race and trust. Annual Review of Sociology, 36, 453475.

Social Development Department, World Bank. (2012). World Development Report.

https://siteresources.worldbank.org/INTWDR2012/Resources/7778105-1299699968583/77862101315936222006/Complete-Report.pdf

Tajfel, H., Turner, J. C., Austin, W. G., \& Worchel, S. (1979). An integrative theory of intergroup conflict. Organizational identity: A reader, 56, 65. Thibaut, J.W., Kelly, H.H. (1959). The Social Psychology of Groups. Wiley.

Thye, S. R., Yoon, J., \& Lawler, E. J. (2002). The theory of relational cohesion: Review of a research program. Advances in Group Processes, 19, 139-166.

Tobin, S. J., Vanman, E. J., Verreynne, M., \& Saeri, A. K. (2015). Threats to belonging on Facebook: Lurking and ostracism. Social Influence, 10(1), 31-42. Tomasello, T. K., Lee, Y., \& Baer, A. P. (2010). 'New media'research publication trends and outlets in communication, 19902006. New media \& society, 12(4), 531-548.

Walton, E., \& Hardebeck, M. (2016). Multiethnic neighborhoods on the ground: Resources, constraints, and sense of community. Du Bois Review: Social Science Research on Race, 13(2), 345-363. Whitaker, M. S. (2013). Anxiety/uncertainty management and its relationship to community as an anxiety management mechanism: A mixed methods, across case study of online graduate students (Doctoral dissertation, University of Alabama Libraries).

Wilkinson, R. G., \& Pickett, K. (2009). The spirit level: Why more equal societies almost always do better. Allen Lane.

Woolcock, M. (2011). What Distinctive Contribution Can Social Cohesion Make to Development Theory, Research, and Policy?. In Organisation for Economic Cooperation and Development International Conference on Social Cohesion and Development, Paris, January (Vol. 20).

Yoo, Y., \& Alavi, M. (2001). Media and group cohesion: Relative influences on social presence, task participation, and group consensus. MIS quarterly, 371-390. 
INTERNATIONAL JOURNAL OF ACADEMIC RESEARCH IN BUSINESS AND SOCIAL SCIENCES

Vol. 10, No. 15, Youth and Community Wellbeing: Issues, Challenges and Opportunities for Empowerment V1. 2020, E-ISSN: 2222-6990 @ 2020 HRMARS

Supporting Information

Appendix 1. The pattern of SNS usage

Table 6: Pattern of SNS usage

\begin{tabular}{|c|c|c|}
\hline Indicator & Mean/Frequency & SD/Percentage \\
\hline Years of SNS usage & 8.39 & 3.618 \\
\hline $1-10$ years & 242 & $80.7 \%$ \\
\hline $11-20$ years & 56 & $18.7 \%$ \\
\hline$>20$ years & 2 & $0.7 \%$ \\
\hline \multicolumn{3}{|l|}{ Social media usage } \\
\hline Facebook & 238 & $79.3 \%$ \\
\hline Usage per time/day & 4.90 & 7.493 \\
\hline Hours per usage/day & .45 & .799 \\
\hline Minutes per usage/day & 13.25 & 14.502 \\
\hline WhatsApp & 296 & $98.7 \%$ \\
\hline Usage per time/day & 17.27 & 18.956 \\
\hline Hours per usage/day & .19 & .527 \\
\hline Minutes per usage/day & 13.15 & 11.325 \\
\hline Twitter & 102 & $34.0 \%$ \\
\hline Usage per time/day & 2.33 & 5.579 \\
\hline Hours per usage/day & .12 & .389 \\
\hline Minutes per usage/day & 4.06 & 9.048 \\
\hline WeChat & 89 & $29.7 \%$ \\
\hline Usage per time/day & 2.15 & 7.600 \\
\hline Hours per usage/day & .05 & .257 \\
\hline Minutes per usage/day & 3.37 & 8.454 \\
\hline Instagram & 248 & $82.7 \%$ \\
\hline Usage per time/day & 9.45 & 16.215 \\
\hline Hours per usage/day & .27 & .550 \\
\hline Minutes per usage/day & 12.89 & 13.248 \\
\hline Telegram & 129 & $43.0 \%$ \\
\hline Usage per time/day & 1.78 & 4.319 \\
\hline Hours per usage/day & .09 & .325 \\
\hline Minutes per usage/day & 5.38 & 10.316 \\
\hline YouTube & 273 & $91.0 \%$ \\
\hline Usage per time/day & 5.28 & 6.214 \\
\hline Hours per usage/day & .99 & 1.252 \\
\hline Minutes per usage/day & 13.03 & 15.340 \\
\hline
\end{tabular}

